\title{
Media Pembelajaran Aksara Sumbawa Berbasis Multimedia Pada Pelajaran Muatan Lokal
}

\author{
Amri Rachmat (09018011) ${ }^{1,}$, Wahyu Pujiyono (0504116601)² \\ Teknik Informatika Universitas Ahmad Dahlan, Jl. Ringroad Selatan, Bantul, Yogyakarta 55191, Indonesia \\ ${ }^{1}$ celix.blacklist@gmail.com; ${ }^{2}$ yywahyup@gmail.com
}

\begin{abstract}
ABSTRAK
Muatan Lokal adalah mata pelajaran yang berisikan materi tentang aksara Sumbawa. Siswa membutuhkan ketekukan dalam mengenal dan menulis untuk dapat memahami materi pelajaran tersebut. Terdapat siswa yang tidak mengikuti arahan guru pada proses belajar di kelas. Hal ini berdampak pada penyerapan materi pelajaran yang tidak optimal.Hal ini berdampak pada rendahnya nilai rata-rata ulangan harian yang didapatkan oleh Kelas VII di SMP Negeri 1 Sumbawa. Tujuan dari penelitian ini yaitu menghasilkan sebuah aplikasi media pembelajaran tentang aksara Sumbawa serta meningkatkan nilai rata-rata kelas VII di SMP Negeri 1 Sumbawa pada mata pelajaran Muatan Lokal.

Subyek dalam penelitian ini adalah media pembelajaran aksara Sumbawa untuk kelas VII di SMP Negeri 1 Sumbawa. Metodologi yang digunakan dalam penelitian ini yaitu dengan melakukan pengumpulan data terkait topik penelitian melalui studi pustaka, wawancara dan observasi. Metode pengamatan yang dilakukan dengan cara observasi langsung ke objek penelitian adalah cara siswa belajar, bagaimana guru mengajar dan nilai tes siswa. Tahap pengembangan aplikasi meliputi analisis kebutuhan (pengguna dan sistem), konsep desain (skenario pembelajaran kelas, skenario pembelajaran berbasis ICT), perancangan system (menu, diagram navigasi, storyboard), implementasi sistem dan pengujian sistem.

Pengujian system menggunakan uji T-test oleh 40 orang siswa kelas VII. Terdapat perbedaan yang signifikan pada hasil pengujian dalam peningkatan nilai yang di dapatkan sebelum dan sesudah dilakukan uji coba. Hal ini menunjukkan bahwa aplikasi media pembelajaran aksara Sumbawa memiliki pengaruh terhadap peningkatan nilai rata-rata yang di dapatkan oleh siswa Kelas VII di SMP Negeri 1 Sumbawa.
\end{abstract}

Ciptaan disebarluaskan di bawah lisensi CC-BY-SA.

Kata kunci: Multimedia, Media Pembelajaran, Aksara Sumbawa

\section{PENDAHULUAN}

Muatan Lokal adalah mata pelajaran yang berisikan materi tentang aksara Sumbawa. Materi pelajaran berupa pengenalan aksara mulai dari cara mengucapkan dan menulis aksara. Siswa membutuhkan ketekukan dalam mengenal dan menulis untuk dapat memahami materi pelajaran tersebut. Pada proses pembelajaran terdapat siswa yang tidak mendengarkan guru menjelaskan materi di depan kelas. Hal ini berdampak pada penyerapan materi pelajaran yang tidak optimal. Pada saat siswa melakukan latihan menulis aksara, guru tidak bisa mengawasi seluruh siswa karena keterbatasan dalam pengawasan. Proses pembelajaran yang kurang optimal berdampak pada nilai latihan dan evaluasi siswa di bawah rata-rata kelas. 
Berdasarkan data nilai ulangan harian Muatan Lokal kelas VII SMP Negeri 1 Sumbawa Besar Tahun Pelajaran 2015/2016, diperoleh rata-rata nilai 60.55. Dapat disimpulkan bahwa hasil nilai ulangan harian siswa masih tergolong rendah dan belum mencapai nilai kriteria ketuntasan siswa (KKM) yang bernilai 70. Maka dari itu diperlukan sebuah media pembelajaran sebagai jembatan antara guru dan peserta didik agar proses belajar mengajar lebih efektif. Media pembelajaran yang dapat membantu siswa dalam menulis dan membaca aksara Sumbawa. Media pembelajaran yang dapat membantu keterbatasan guru dalam pengawasan murid di kelas.

Computer-Aided Instruction (CAI) adalah teknologi komputer yang berkembang untuk membantu proses belajar mengajar. Contoh dari aplikasi CAI antara lain latihan dan praktek, visualisasi objek yang kompleks dengan menggunakan komputer, komunikasi antara murid dan guru melalui komputer [1]. Menggunakan CAI dapat dihasilkan aplikasi materi pelajaran aksara Sumbawa dengan metode tutorial yang interaktif. Metode tutorial cara pengenalan, pengucapan dan penulisan aksara. Aplikasi yang diharapakan dapat meningkatkan tingkat penyerapan materi pelajaran oleh siswa.

\section{Kajian Pustaka}

\subsection{Kajian Penelitian Terdahulu}

Penelitian sebelumnya yang dilakukan oleh Wahyudi [2] dengan judul Aplikasi Pembelajaran Aksara Satera Jontal Berbasis Android. Aplikasi ini menyediakan 3 Menu yaitu menu Huruf, menu Kamus, dan Kuis. Pada menu huruf terdapat materi cara menulis aksara dan contoh penggunaan aksara dalam suatu kata. Pada menu kamus, pengguna dapat menerjemahkan bahasa Indonesia ke bahasa Sumbawa lalu menampilkannya ke dalam huruf aksara Sumbawa. Pada menu kuis, pengguna dapat berlatih menjawab soal tebak kata mengenai materi aksara. Penelitian yang dilakukan Wahyudi ini memiliki perbedaan dengan penelitian yang saya lakukan yaitu aplikasi ini berbasiskan android. Siswa sekolah menengah pertama khususnya kelas VII belum memiliki telepon selular berbasis android untuk digunakan di sekolah. Selain itu pada penelitian ini belum ada menu pengucapan setiap aksara.

Penelitian sebelumnya yang dilakukan oleh Khusnul Lutfi Marfuatun Nafi dengan judul Pembelajaran Aksara Jawa Berbasis Multimedia Interaktif Menggunakan Macromedia Flash 8 [3]. Pengembangan media pembelajaran ini bertujuan untuk menumbuhkan semangat, minat, serta mengaktifkan siswa belajar mandiri. Pada aplikasi ini terdapat menu yang berisi tentang materi, contoh aplikasi, dan evaluasi. Pada menu materi terdapat bentuk aksara, nama, deskripsi atau keterangan, serta suara untuk menyampaikan nama atau cara pengucapan aksara. Penelitian yang dilakukan Khusnul Lutfi ini memiliki perbedaan dengan penelitian yang saya lakukan yaitu aplikasi pembelajaran ini tidak memiliki materi cara penulisan aksara.

\subsection{Landasan Teori}

Computer-Aided Instruction (CAI) adalah teknologi komputer yang berkembang dengan sangat pesat untuk membantu proses belajar mengajar. CAI disebut juga sebagai Computer-Aided Instruction. Contoh dari aplikasi CAI antara lain latihan dan praktek, visualisasi objek yang kompleks dengan menggunakan komputer, dan komunikasi antara murid dan guru melalui komputer.

Kelebihan computer aided instruction salah satunya adalah sebagai metode pengajaran yang digunakan untuk membantu pengajar dalam mengajarkan materi secara interaktif dalam sebuah program tutorial dengan menggunakan suatu aplikasi komputer. Dalam menyampaikan berbagai proses, seperti penyajian materi kepada pemakai untuk dibaca dan dipelajari, memberikan petunjuk dan latihan mengenai materi yang dipelajari, memberikan pertanyaan dan masalah untuk dijawab serta memberikan penilaian dari hasil belajar kepada pemakai [1] . 


\subsection{Aksara Sumbawa}

Tabel 1. Huruf Dasar Aksara Sumbawa

\begin{tabular}{|c|c|c|}
\hline No & Aksara & Bunyi \\
\hline 1. & & KA \\
\hline 2. & & GA \\
\hline 3. & & NGA \\
\hline 4. & & PA \\
\hline 5. & & BA \\
\hline 6. & & MA \\
\hline 7. & & TA \\
\hline 8. & & DA \\
\hline 9. & & NA \\
\hline 10. & & $\mathrm{CA}$ \\
\hline 11. & & JA \\
\hline 12. & & NYA \\
\hline 13. & & YA \\
\hline
\end{tabular}

\begin{tabular}{|c|c|}
\hline 14. & RA \\
\hline 15. & LA \\
\hline 16. & WA \\
\hline 17. & SA \\
\hline 18. & A \\
\hline 19. & HA \\
\hline 20. & $Z A$ \\
\hline 21. & KHA \\
\hline 22. & SYA \\
\hline 23. & FA \\
\hline 24. & $\mathrm{QA}$ \\
\hline 25. & DHA \\
\hline
\end{tabular}

\section{Metode Penelitian}

\subsection{Subjek Penelitian}

Subjek dari penelitian ini adalah media pembelajaran aksara Sumbawa untuk Kelas VII SMP Negeri 1 Sumbawa yang bertujuan untuk meningkatkan nilai rata-rata kelas. Media pembelajaran yang dihasilkan dalam bentuk media pembelajaran berbasis desktop. Pengguna dari media pembelajaran aksara Sumbawa ini adalah guru dan siswa. Guru diharapkan akan mampu menggunakan media dalam proses pembelajaran di dalam kelas dan siswa mampu mengeksplor sendiri kemampuannya. Dengan demikian, guru dan siswa akan mampu belajar aktif bersama-sama untuk meningkatkan nilai rata-rata kelas.

\subsection{Alat Penelitian}

Alat yang digunakan dalam penelitian yaitu perangkat keras (hardware) dan perangkat lunak (software). 
1. Perangkat Keras

a. Spesifikasi perangkat keras yang digunakan dalam penelitian ini yaitu :

b. Notebook VAIO PVCCW16FG * Intel Pentium InsideTM

c. RAM DDR3 4GB

d. Harddisk 500GB

e. Printer HP Deskjet 101046

2. Perangkat Lunak

a. Spesifikasi perangkat lunak yang digunakan dalam penelitian ini yaitu :

b. Sistem Operasi : Windows 7 Ultimate

c. Bahasa Pemrograman : Action Script

d. Tools : Adobe Flash Professional CS5

e. Pengolahan Gambar : Adobe Flash Professional CS5

f. Pengolahan Suara: Adobe Soundbooth Professional CS5

\subsection{Tahap Perancangan Sistem}

\section{a. Perancangan Konsep}

Perancangan konsep merupakan tahap penentuan secara keseluruhan mengenai perancangan konsep program aplikasi yang akan dibangun, agar mempunyai tujuan yang jelas untuk mempermudah user. Dalam merancang program aplikasi multimedia interaktif harus melibatkan elemen-elemen multimedia yang meliputi gambar, teks, suara, dan animasi. Pada prancangan konsep media pembelajaran, materi yang disajikan harus memiliki tujuan yang jelas untuk meningkatkan kompetensi siswa dan tidak lepas dari skenario pembelajaran kelas dan skenario pembelajaran berbasis ICT.

b. Perancangan Menu

Perancangan menu berfungsi untuk memberikan pilihan menu-menu yang tersedia dalam aplikasi. Sistem menu merupakan bagian yang sangat penting untuk menunjukkan kemampuan dan fasilitas aplikasi pada user.

c. Perancangan Diagram Navigasi

Merupakan rancangan alur dari program yang menunjukkan status penyebab perubahan pada menu. Pada perancangan aplikasi ini, penulis menggunakan desain navigasi agar pemakai dapat mudah dalam menelusuri program.

\section{d. Perancangan Storyboard}

Digunakan untuk penggambaran jalan cerita sesuai dengan isi cerita dan berisi tentang pengambilan sudut gambar, pengisian suara, serta efek-efek khusus. Penggambaran jalan cerita berbentuk potongan gambar atau komik yang disertai penjelasan alur cerita, sehingga program aplikasi yang dibuat menjadi user friendly. .

\subsection{Implementasi}

Tahap ini merupakan tahap pembuatan aplikasi berdasarkan hasil rancangan yang ada menggunakan Adobe Flash Professional CS5 dan bahasa pemrograman action script. Sedangkan untuk pengimplementasian kepada user aplikasi akan di jadikan sebagai file ".exe " dan atau dibuat dalam bentuk CD Drive sehingga bisa di instalasi berulang-ulang.

\subsection{Pengujian Sistem}

Tahap ini merupakan pengujian aplikasi yang telah dibuat. Pengujian sistem sangat diperlukan untuk menentukan keberhasilan suatu sistem, dan melakukan perbaikan-perbaikan jika masih terjadi kesalahan. 


\section{Hasil Dan Pembahasan}

\subsection{Analisis Kebutuhan}

- Kebutuhan Pengguna (user requirement)

a. Siswa

Aplikasi pembelajaran ini dijadikan alat alternatif dalam proses pembelajaran. Siswa dapat mempelajari materi, menjawab pertanyaan dan evaluasi latihan. Tujuannya adalah untuk memudahkan siswa belajar mandiri tanpa harus dijelaskan oleh guru, memudahkan siswa mengerjakan latihan soal dan evaluasi secara mandiri, dan memperoleh nilai evaluasi yang memuaskan.

b. Guru

Aplikasi pembelajaran ini dirancang sebagai salah satu alternatif alat bantu dalam proses pembelajaran Aksara Sumbawa, yang nantinya diharapakan akan dapat mempermudah guru dalam mengajar di kelas.

- Kebutuhan Sistem

Analisis kebutuhan sistem adalah analisis kebutuhan - kebutuhan data dalam perancangan sistem. Aplikasi media pembelajaran dibuat dengan menggunakan Adobe Flash CS 5. Perangkat lunak lain yang mendukung aplikasi ini adalah CorelDraw X6, Adobe Soundbooth Professional CS5.

\subsection{Perancangan Konsep}

Konsep desain media pembelajaran, materi yang disajikan harus memiliki tujuan yang jelas untuk meningkatkan kompetensi siswa dan tidak lepas dari skenario pembelajaran kelas dan skenario pembelajaran berbasis ICT. Empat pertemuan 4x70 menit sesuai dengan Rencana Pelaksanaan Pembelajaran (RPP). Materi yang harus disampaikan tentang mengenal dan menulis aksara sumbawa. Dalam pembuatan aplikasi multimedia melibatkan elemen multimedia yang meliputi teks, suara, gambar, dan animasi. Tahap perancangan meliputi analisis kebutuhan (pengguna dan sistem), konsep desain (skenario pembelajaran kelas, skenario pembelajaran berbasis ICT), perancangan menu, perancangan diagram navigasi, perancangan isi (storyboard), desain teks, desain grafis.

\subsection{Perancangan Isi}

Fungsi storyboard adalah menerjemahkan isi skenario secara visual atau penggambaran secara singkat.

Tabel 2. Storyboard Display

\begin{tabular}{|c|c|c|c|}
\hline No. & Visualisasi & Deskripsi & Multimedia \\
\hline 1. & $\begin{array}{l}\text { MEDIA PEMBELAJARAN } \\
\text { AKSARA SUMBAWA }\end{array}$ & $\begin{array}{l}\text { Merupakan } \\
\text { tampilan awal } \\
\text { aplikasi yang berisi } \\
\text { judul aplikasi dan } \\
\text { dan tombol masuk. }\end{array}$ & $\begin{array}{l}\text { Sound: } \\
\text { Sound.wav }\end{array}$ \\
\hline
\end{tabular}




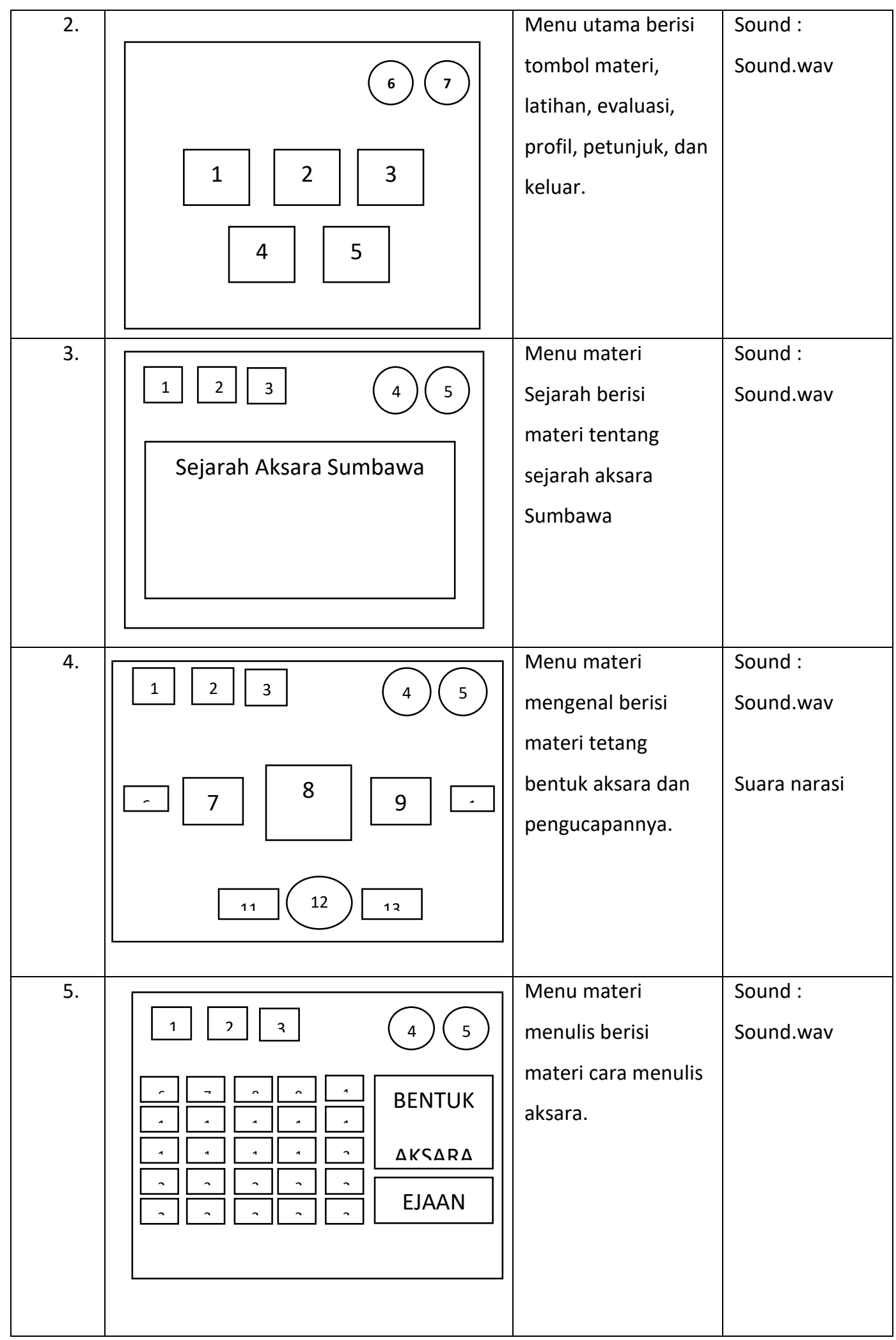




\begin{tabular}{|c|c|c|c|}
\hline 6. & SOAL & $\begin{array}{l}\text { Menu latihan berisi } \\
\text { latihan soal tentang } \\
\text { akasara sumbawa.. }\end{array}$ & $\begin{array}{l}\text { Sound: } \\
\text { Sound.wav }\end{array}$ \\
\hline 7. & EVALUASI & $\begin{array}{l}\text { Menu evaluasi berisi } \\
\text { soal evaluasi } \\
\text { tentang aksara } \\
\text { sumbawa. }\end{array}$ & $\begin{array}{l}\text { Sound: } \\
\text { Sound.wav }\end{array}$ \\
\hline 8. & $\begin{array}{c}\text { NAMA } \\
\text { ALAMAT }\end{array}$ & $\begin{array}{l}\text { Menu profil berisi } \\
\text { info pembuat } \\
\text { aplikasi }\end{array}$ & $\begin{array}{l}\text { Sound: } \\
\text { Sound.wav }\end{array}$ \\
\hline 9. & PETUNJUK & $\begin{array}{l}\text { Menu petunjuk } \\
\text { berisi info } \\
\text { penggunaan } \\
\text { tombol. }\end{array}$ & $\begin{array}{l}\text { Sound: } \\
\text { Sound.wav }\end{array}$ \\
\hline
\end{tabular}




\subsection{Implementasi Sistem}

a. Tampilan Halaman Pembuka

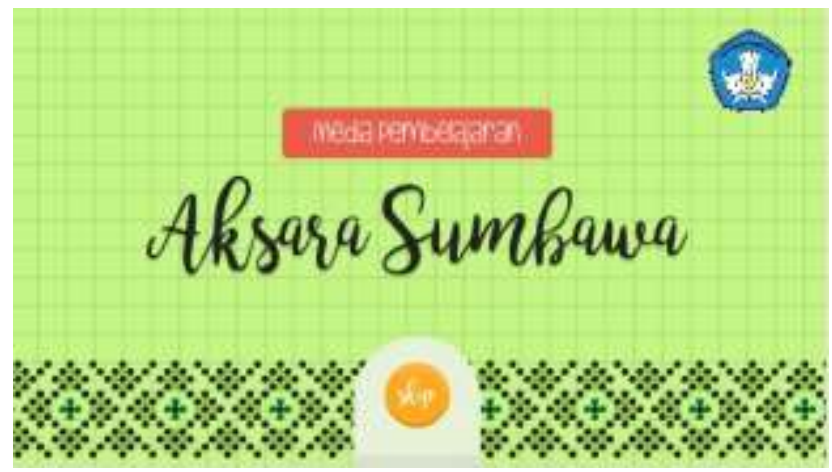

Gambar 1. Halaman Pembuka

Gambar 1 merupakan halaman pembuka dan pertama kali muncul ketika user menggunakan aplikasi media pembelajaran Aksara Sumbawa berbasis multimedia dengan konsep computer aided instruction studi kasus pada SMP Negeri 1 Sumbawa Besar Kelas VII. .

b. Halaman Menu Utama

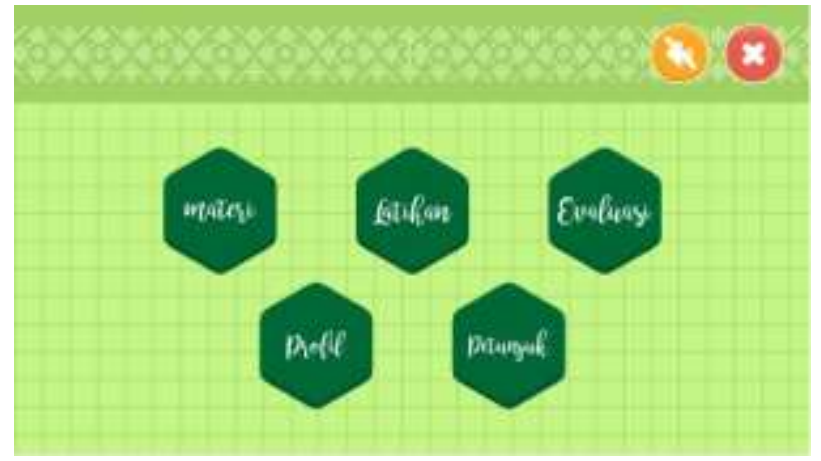

Gambar 2. Halaman Utama

Gambar 2 merupakan halaman utama dari aplikasi media pembelajaran Aksara Sumbawa. Halaman ini menghubungkan link halaman yang satu dengan yang lainnya. Siswa diberikan kebebasan untuk memilih materi ajar yang akan dipilih. .

c. Tampilan Halaman Materi Sejarah

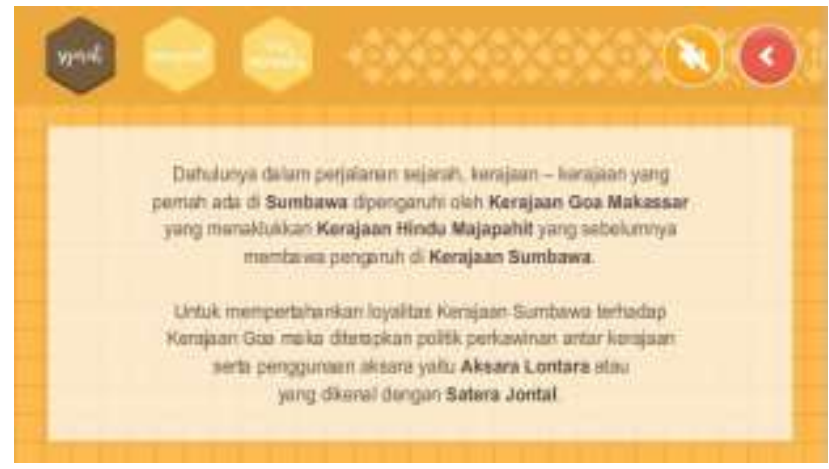

Gambar 3. Tampilan Halaman Materi Sejarah 
Gambar 3 adalah halaman materi sejarah. Halaman ini merupakan satu dari 3 sub-halaman Materi. Pada halaman ini menjelaskan materi tentang sejarah Aksara Sumbawa. .

d. Tampilan Halaman Materi Mengenal

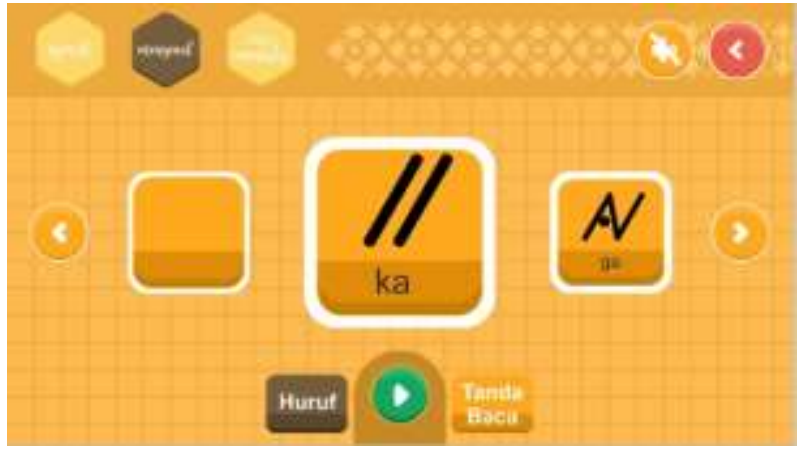

Gambar 4. Tampilan Halaman Materi Mengenal

Gambar 4 adalah halaman materi mengenal aksara. Halaman ini merupakan satu dari 3 sub-halaman Materi. Pada halaman ini siswa dapat mengenal bentuk huruf dan pengucapan aksara.

e. Tampilan Halaman Materi Cara Menulis

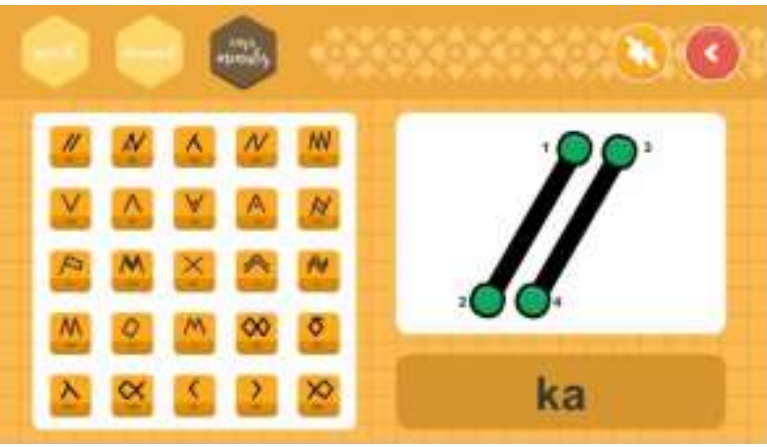

Gambar 5. Tampilan Halaman Materi Cara Menulis

Gambar 5 adalah halaman materi cara menulis. Halaman ini merupakan satu dari 3 sub-halaman materi. Pada halaman ini siswa mempelajari cara penulisan aksara Sumbawa. Terdapat titik-titik bernomor yang jika dihubungkan akan membentuk aksara. Cara menghubungkannya yaitu dengan mengklik titik awal lalu menariknya ke titik selanjutnya sesuai urutan.

f. Tampilan Halaman Latihan

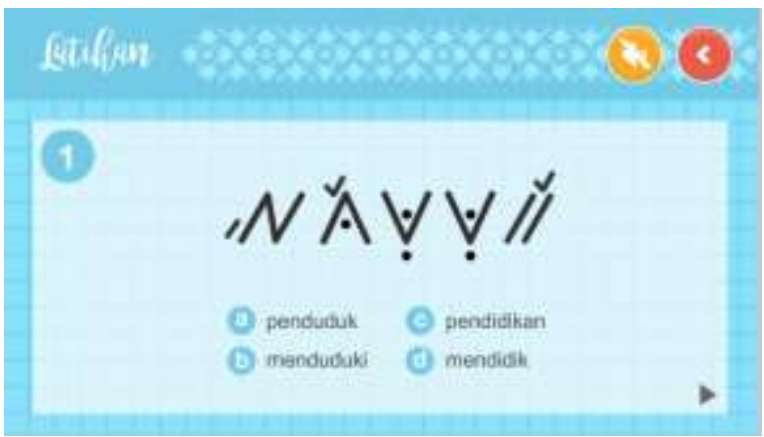

Gambar 6. Tampilan Halaman Latihan

Gambar 6 merupakan halaman latihan soal. Halaman ini berisi soal latihan untuk melatih pemahaman siswa terhadap materi yang sudah di pelajari sebelumnya. Siswa dapat bebas memilih soal 
dengan mengklik tombol panah ke kanan untuk soal selanjutnya dan mengklik tombol panah ke kiri untuk soal sebelumnya. Siswa dapat memilih jawaban sampai dengan pilihan yang benar dikarenakan masih dalam tahap latihan. .

g. Tampilan Halaman Evaluasi

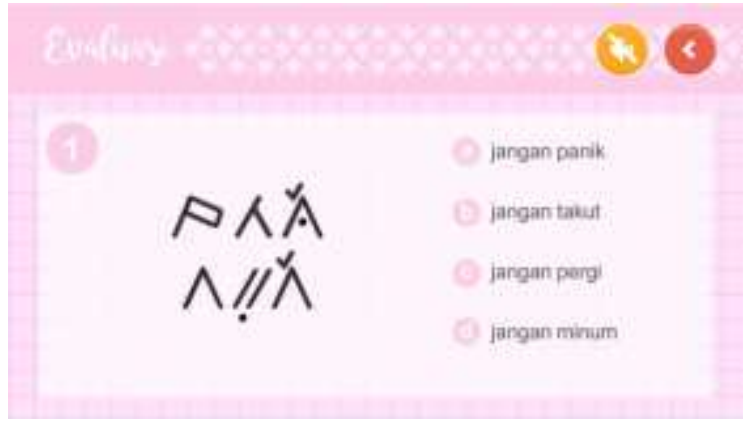

Gambar 7. Tampilan Halaman Evaluasi

Gambar 7 merupakan halaman evaluasi. Halaman ini berisi soal evaluasi yang bertujuan untuk mengetahui seberapa besar pemahaman siswa terhadap materi Aksara Sumbawa. Siswa dapat mengerjakan 10 butir soal pilihan ganda yang bersifat continue. Perbedaan dengan menu latihan soal, siswa tidak dapat memilih soal dengan bebas. Siswa di arahkan ke soal baru setelah mengerjakan sebuah soal.

h. Tampilan Halaman Nilai Evaluasi

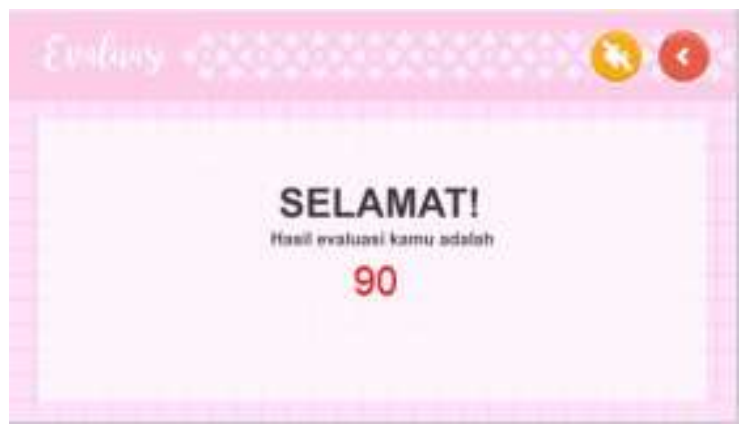

Gambar 8. Tampilan Halaman Nilai Evaluasi

Gambar 8 merupakan halaman nilai evaluasi. Siswa akan mendapatkan skor nilai setelah mengerjakan soal evaluasi. Nilai tersebut akan menunjukkan pemahaman siswa terhadap aksara.

i. Tampilan Halaman Profil

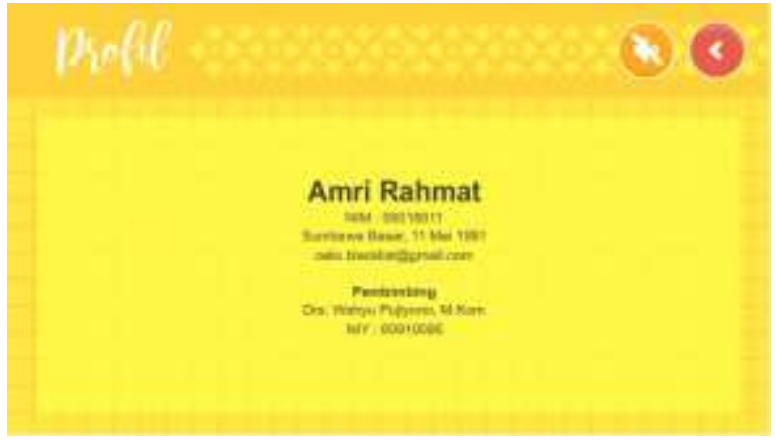

Gambar 9. Tampilan Halaman Profil 
Gambar 8 merupakan halaman profil. Halaman ini menampilkan sedikit informasi tentang pembuat aplikasi.

\subsection{Pengujian Sistem}

a. Blackbox Test

Pengujian black box testing haruslah dilakukan oleh orang yang mengerti akan sistem yang berjalan. Pengujian black box dilakukan oleh guru pengampu mata pelajaran Muatan Lokal untuk Kelas VII di SMP Negeri 1 Sumbawa Besar yaitu Syamsiah S.Pd. Pengujian dilakukan dengan memberikan lembar isian kepada tester, kemudian tester menuliskan hasil dari pengujian pada lembar isian yang sudah diberikan. Lembar isian terdiri dari Test-ID, Function Name, Description, Expected Result, dan Actual Result. Contoh Black box test dapat dilihat seperti dibawah ini : .

Tabel 3. Black Box Testing

\begin{tabular}{|c|c|c|c|c|}
\hline $\begin{array}{c}\text { Test } \\
\text { ID }\end{array}$ & Function Name & Description & Expected Result & Actual Result \\
\hline 3 & $\begin{array}{l}\text { Tampil Menu Materi } \\
\text { Cara Menulis }\end{array}$ & $\begin{aligned} \text { Syarat: } & \\
\text { 1. } & \text { Pengguna sudah } \\
& \text { melewati Test } 1 \\
& \text { dan } 2 . \\
\text { 2. } & \text { Pengguna klik } \\
& \text { button materi } \\
& \text { "CARA MENULIS". }\end{aligned}$ & & \\
\hline & & $\begin{array}{l}\text { 1. Pengguna klik } \\
\text { button } 25 \text { macam } \\
\text { aksara. } \\
\text { 2. Pengguna drag } \\
\text { mouse. }\end{array}$ & $\begin{array}{c}\text { Tampil halaman menulis } 25 \\
\text { macam aksara. }\end{array}$ & True \\
\hline
\end{tabular}

Cara pengisian black box test adalah sebagai berikut; Test-ID merupakan urutan halaman yang ditampilkan, Test-ID perlu diperhatikan karena sebagai syarat pada description. Expected result merupakan hasil keluaran yang diharapkan. Sedangkan actual result adalah hasil yang nyata. Apabila expected result sama dengan actual result, maka actual result diberi kata True. Jika actual result tidak sesuai dengan expected result maka diberi kata False dan aplikasi harus diperbaiki kembali. Pada pengujian ini, tester mengisi True pada semua kolom Actual Result. Hal ini berarti menunjukkan hasil keluaran pada aplikasi sesuai dengan yang diharapkan.

\section{b. Whitebox Test}

White Box Testing merupakan pengujian sistem yang didasarkan pada pengecekan terhadap detail perancangan, menggunakan struktur kontrol dari desain program secara prosedural. Pengujian dilakukan berdasarkan bagaimana suatu software menghasilkan output dari input. Pengujian dengan metode white box test haruslah menggunakan tester yang ahli tentang source code yang digunakan, atau biasa disebut dengan programmer. Pada penelitian kali ini pengujian dilakukan oleh Muhammad Almahdi S.T. Hasil dari pengujian white box testing ini dapat dilihat pada table dibawah ini : . 
Tabel 4. White Box Test

\begin{tabular}{|c|l|l|l|c|}
\hline $\begin{array}{c}\text { Test } \\
\text { ID }\end{array}$ & Module Name & \multicolumn{1}{|c|}{ True Outcome } & \multicolumn{1}{|c|}{ False Income } & Actual Result \\
\hline 4 & Materi & Kondisi Materi Aplikasi : & & \\
\hline & & $\begin{array}{l}\text { 1. Terdapat materi tentang } \\
\text { Sejarah Aksara. }\end{array}$ & $\begin{array}{l}\text { Materi tentang Sejarah } \\
\text { Akasara tidak dapat } \\
\text { ditampilkan. }\end{array}$ & True \\
\hline & & $\begin{array}{l}\text { 2. Terdapat materi tentang } \\
\text { Mengenal Aksara }\end{array}$ & $\begin{array}{l}\text { Materi tentang Mengenal } \\
\text { Aksara tidak dapat } \\
\text { ditampilkan. }\end{array}$ & True \\
\hline & & $\begin{array}{l}\text { 3. Terdapat materi tentang } \\
\text { cara menulis aksara }\end{array}$ & $\begin{array}{l}\text { Materi tentang cara menulis } \\
\text { aksara tidak dapat } \\
\text { ditampilkan. }\end{array}$ & True \\
\hline
\end{tabular}

Cara pengisian white box test adalah sebagai berikut; Test-ID merupakan urutan halaman yang ditampilkan, module name merupakan urutan kejadian dalam aplikasi mulai dari persiapan hingga penutup yang memiliki true outcome dan false income. True outcome merupakan kejadian sebenarnya, sedangkan false income merupakan skenario terburuk yang tidak terjadi pada saat aplikasi digunakan. Tester mengisi True atau False pada kolom Actual Result sesuai dengan pada saat pengujian. Pada pengujian ini, tester mengisi True pada semua kolom Actual Result. Ini menunjukkan hasil keluaran pada aplikasi sesuai dengan yang diharapakan. .

\section{c. Post Test}

Pengujian sistem yang dilakukan oleh siswa mulai dari membaca materi sampai dengan mengerjakan evaluasi, siswa tidak menemukan kesulitan dalam menggunakan aplikasi. Selanjutnya, siswa diberikan lembar post test sebagai acuan keberhasilan aplikasi dalam membantu siswa mempelajari materi aksara. Post test juga digunakan sebagai bahan perbandingan sebelum dan sesudah menggunakan aplikasi. Tabel 5 dibawah ini merupakan data nilai siswa Kelas VII di SMP Negeri 1 Sumbawa Besar. Tabel ini berisikan nilai uji coba sebelum dan setelah menggunakan media pembelajaran. Setelah mendapatkan data nilai melalui evaluasi, selanjutnya nilai di olah dengan metode yang telah ditentukan sebelumnya. Daftar nilai dapat dilihat pada Tabel 5 berikut ini : .

Tabel 5. Hasil Uji Coba Nilai Pre-Test dan Post-Test Kelas IV di SMP Negeri 1 Sumbawa Besar

\begin{tabular}{|c|l|c|c|}
\hline \multirow{2}{*}{ No } & \multicolumn{2}{|c|}{ Nama Siswa } & \multicolumn{2}{c|}{ Nilai Uji Coba } \\
\cline { 3 - 4 } & & Sebelum & Setelah \\
\hline 1. & AFIFAH PUTRI CAHYANI & 64 & 82 \\
\hline 2. & AGUS TRY HARTONO & 58 & 84 \\
\hline 3. & AJENG NURSANTI TRI HANDINI & 72 & 88 \\
\hline 4. & ANNI ZAINATUL HUSNA & 44 & 76 \\
\hline 5. & ASIH LARASWATI & 58 & 66 \\
\hline 6. & BINARSIH NAWAN HANAYATI & 66 & 78 \\
\hline 7. & DHEVIA NABHILAH & 52 & 80 \\
\hline 8. & DIENY RESKI OKARIMA & 76 & 90 \\
\hline 9. & DIKI ZULKARNAIN & 54 & 68 \\
\hline 10. & EKA NURHIDAYATI & 62 & 76 \\
\hline 11. & ELSA OKTARINA & 62 & 78 \\
\hline 12. & FARIDAH LUTFIAH & 64 & 80 \\
\hline 13. & FEBRIANI EKASARI & 72 & 86 \\
\hline
\end{tabular}




\begin{tabular}{|c|l|c|c|}
\hline 14. & IMAM ABDUL HAFIZH & 56 & 76 \\
\hline 15. & INTAN DWI RAHMI & 60 & 80 \\
\hline 16. & INTAN PUTRI SARI & 50 & 64 \\
\hline 17. & ISRONI ROMADHON & 62 & 76 \\
\hline 18. & JANEKA SAFITRI & 56 & 70 \\
\hline 19. & JULIALITA MUHARIANI & 80 & 92 \\
\hline 20. & M.AFIF PRAWIRA & 48 & 72 \\
\hline 21. & MARIA ULFA & 74 & 80 \\
\hline 22. & M. DECKY FERNANDO & 60 & 72 \\
\hline 23. & MELSA TRIANDI & 40 & 68 \\
\hline 24. & MENIK JULI ASTUTIK & 62 & 72 \\
\hline 25. & MERY ASTUTI & 70 & 74 \\
\hline 26. & MGS. MUHAMMAD NURSALIM & 60 & 86 \\
\hline 27. & MUTIA NOOR HERMAYA & 78 & 88 \\
\hline 28. & PIRSA ANGGRAINI & 58 & 72 \\
\hline 29. & RANI INDAH PURWANTI & 66 & 70 \\
\hline 30. & REZA DAMAYANTI & 52 & 58 \\
\hline 31. & RIA AFRIANGKI & 52 & 60 \\
\hline 32. & RINJANI ROLA NAWANG WULAN & 50 & 58 \\
\hline 33. & RIRIN HIDAYATI & 40 & 62 \\
\hline 34. & SELKA MERLIANI & 70 & 74 \\
\hline 35. & SEPTIANSYAH SURAHMAN & 68 & 84 \\
\hline 36. & SISKA ELVA SARI & 72 & 78 \\
\hline 37. & TIARA PUTRI WIGUNA & 70 & 88 \\
\hline 38. & YESSI EKA PRATIWI & 56 & 76 \\
\hline 39. & YUGA DWI PUTRA & 52 & 68 \\
\hline 40. & YULIA TRIANDANI & 56 & 84 \\
\hline & JUMLAH & 2426 & 3034 \\
\hline & RATA-RATA & 60.55 & 75.85 \\
\hline
\end{tabular}

\section{d. Uji T-Test}

Setelah mendapatkan data nilai melalui evaluasi, selanjutnya nilai diolah dengan metode yang telah ditentukan yaitu uji T-test.

T-Test

\begin{tabular}{|c|c|c|c|c|c|}
\hline \multicolumn{6}{|c|}{ Pair ed Samples Statistics } \\
\hline & & Mean & N & Sor Devation & $\begin{array}{l}\text { str. Error } \\
\text { Mean }\end{array}$ \\
\hline \multirow[t]{2}{*}{ Pairt } & Nilas Setelum Uji Caba & 6055 & 40 & 9.933 & 1571 \\
\hline & Niar Setelah Uji Coba & 7585 & 40 & 8868 & 1402 \\
\hline
\end{tabular}

\begin{tabular}{|c|c|c|c|c|}
\hline \multicolumn{5}{|c|}{ A Sampies Carrelations } \\
\hline & & $N$ & Cometabian & डाव. \\
\hline Pair 1 & 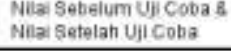 & 40 & .701 & 000 \\
\hline
\end{tabular}

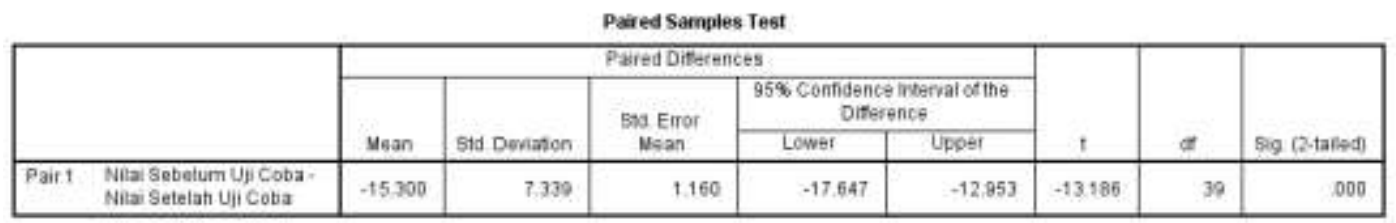

Gambar 10. Hasil Uji T-Test Menggunakan SPSS 
Harga t_hitung lebih kecil dari t_tabel, $(-12.85<-1.991)$ sehingga $\mathrm{H} \_$a diterima dan H_o ditolak. Gambar 9 memperlihatkan penghitungan menggunakan SPSS, di bagian Paired Sample Test dapat dilihat bahwa t_hitung $=-13.186$ dan nilai Sig $=0.000<0.05$ sehingga H_o ditolak. Dikarenakan perhitungan menggunakan SPSS juga menunjukkan bahwa H_o ditolak, maka dapat disimpulkan bahwa terdapat perbedaan / ada peningkatan nilai rata-rata Kelas VII SMP Negeri 1 Sumbawa Besar antara sebelum dan sesudah dilakukan uji coba dengan menggunakan aplikasi media pembelajaran aksara Sumbawa dengan konsep computer aided instruction. .

\section{Kesimpulan}

Kesimpulan yang dapat diambil dari penelitian tugas akhir ini adalah sebagai berikut :

1. Terbangunnya sebuah aplikasi media pembelajaran aksara Sumbawa yang dapat meningkatkan nilai rata-rata Kelas VII di SMP Negeri 1 Sumbawa.

2. Berdasarkan pengujian menggunakan paired $t$ test yang telah dilakukan dengan membandingkan dua sampel yang didapat berupa pre-test dan post-test siswa Kelas VII di SMP Negeri 1 Sumbawa, didapatkan nilai t_hitung $=\quad-13.186$ dan nilai $\mathrm{p}=0.000<0.05$ sehingga $\mathrm{H}$ _o ditolak. Dari hasil tersebut maka dapat disimpulkan bahwa terdapat perbedaan / ada peningkatan nilai rata-rata pada Kelas VII di SMP Negeri 1 Sumbawa antara sebelum dan sesudah dilakukan uji coba dengan menggunakan aplikasi media pembelajaran aksara Sumbawa dengan konsep computer aided instruction.

\section{Daftar Pustaka}

[1] aplikasibidangpendidikan. 2011. CAI (Computer Assisted Instruction). http://aplikasibidangpendidikan.wordpress.com/2011/06/14/cai-computer-assisted-instruction/. Senin 27 Juni 2016.

[2] Wahyudi. 2016. Aplikasi Pembelajaran Aksara Satera Jontal Berbasis Android. Skripsi. Program Studi Teknik Informatika STMIK Akakom, Yogyakarta.

[3] Khusnul Lutfi Marfuatun Nafi.2011.Media Pembelajran Aksara Jawa Berbasis Multimedia Interaktif Menggunakan Macromedia Flash 8. Skripsi. Program Studi Pendidikan Teknik Informatika Universitas Negeri Yogyakarta, Yogyakarta.

[4] HM, A Hijaz., BA, Abdul Gani dan Hasanuddin. 2002. Satera Jontal (Pengenalan dan Penulisannya). Sumbawa : Dinas Pendidikan Nasional Kabupaten Sumbawa. 